\title{
GÁL ZOLTÁN: PÉNZÜGYI PIACOK A GLOBÁLIS TÉRBEN
} A VÁLSÁG SZABDALTA PÉNZÜGYI TÉR

\author{
(Akadémiai Kiadó, Budapest, 2010, 778 o.)
}

\section{ZSIBÓK ZSUZSANNA}

A pénzügyek és térbeli elemzések összekapcsolása a nemzetközi és a hazai irodalomban is új és ígéretes kutatási irány. Részben azért, mert a pénzügyi szféra központi szerepet tölt be a gazdaságban a hazai össztermékhez és a foglalkoztatáshoz való hozzájárulása révén, a különböző ágazatok egyre erősebben függenek - közvetve vagy közvetlenül - a pénzügyektől, illetve a globalizációs tendenciák a pénzügyi szektorban a legelörehaladottabbak, és a társadalomnak egyre nagyobb hányadát közvetlenül is érinti a nemzetközi tőkemozgás. Másrészt azért, mert a pénzügyi piacok alapvető jellemzője a térbeli meghatározottság, s a pénz- és tőkemozgásokat is alapvetően a földrajzi tér különböző helyei között meglévő különbségek, a piacok, az intézmények, a pénzügyi instrumentumok és a piaci információk nagyfokú heterogenitása, illetve területi differenciái indukálják. A nagy kérdés az, hogy hogyan lehet feloldani a globalizálódó és elektronikus pénzügyi tér távolságokat relativizáló hatása és a pénzügyi piaci müködés térbeliségének növekvő fontossága közötti ellentmondást? Vajon a globalizáció oda vezet-e, hogy a pénzvilág tere mindinkább összeszükül, sőt, a térbeliség hatása mellőzhető?

Gál Zoltán monográfiája nemcsak a pénzügyi szektor erős térbeli kötődését igazolja, ami az elektronikus piacok korában is fennáll, de cáfolja a pénzügyi szektor ,kilapulásáról”, virtualizálódásáról, a piaci tér jelentőségvesztéséről szóló elméleteket is. A könyv bemutatja azokat a legfontosabb térformáló tényezőket, amelyek a globalizáció korában a pénzügyi piacok müködését befolyásolják, és feltárja a pénzügyi központoknak a területi fejlődésre gyakorolt hatásait is. Feltérképezi a laikus szemmel nehezen észlelhető pénzmozgásokat, valamint bemutatja a globalizáció és a pénzügyi szféra sajátos kapcsolatát. Az olvasó megismerheti a pénzügyi globalizáció folyamatának időbeli és térbeli dimenzióit, betekintést nyer a globalizálódó pénzügyi tér fejlődési folyamatába, a pénzpiacok térformáló mozgásaiba, a pénzügyi piacok és áramlásaik térbeliségébe. A mü először alkalmazza a regionális, illetve térgazdaságtani szemléletet a pénzügyek területén, és célja, hogy az eddig nem kellően hangsúlyozott térbeli dimenzió vizsgálatát beemelje a hazai pénzügytani szakirodalomba, illetve a ,pénzügyi földrajzi” diszciplínát beemelje a hazai gazdaságföldrajzba (Gál 2000b). Nem marad meg csupán a térfolyamatok vizsgálatának globális szintjén, hanem kitér a régiós, a nemzetgazdasági és a szubnacionális szegmensekre is. A könyv három fő részből áll, melyeket a globális pénzügyi válság folyamatait 
és hosszú távú hatásait bemutató rész egészít ki. Megállapításait a szerző számos friss statisztikai adattal illusztrálja, és ezek áttekinthetőségét táblázatok, grafikonok, s a pénzügytani könyvekben valódi nóvumnak számító térképek segítik (Gál 2009). Emellett az utóbbi évek szaksajtójából és a szakirodalomból válogatott szemléltetőanyagok is részei a témakörök feldolgozásának. Nyelvezete elősegíti, hogy akár a szakemberek, akár a laikusok számára igazi olvasmányélménnyé váljon a monográfia.

A Szerző a gyakorlati szempontok felvázolása során a pénzügyek térbeliségének az elméleti hátterére támaszkodik, melyet a könyv I. részében fejt ki. Az elméleti alapok közé kell sorolnunk elsősorban a Nobel-díjas Paul Krugman által megteremtett új gazdaságföldrajzot, mely a makrogazdaságtani vizsgálatokba beemeli a térbeliség problémáját, és ezzel újragondolt számos már megoldottnak vélt kérdést. Korábban a közgazdaság-tudományban csak a regionális gazdaságtan foglalkozott a gazdaság alapvető térbeli törvényszerüségeivel, míg a mainstream a nemzetgazdaságokat térbeli kiterjedés nélküli pontokként, egypont-gazdaságokként modellezte, és nem vette figyelembe, hogy valójában a legfontosabb közgazdasági kategóriák eleve térbeli jellemzőkkel bírnak. Az új gazdaságföldrajz a közgazdaságtan eredményeinek felhasználásával, matematikai-statisztikai módszerekkel modellezi a térgazdasági folyamatokat. Ebből az irányzatból vált külön a pénzügyi földrajz, mely a gazdaságban zajló pénzügyi folyamatokat térbeli szempontból vizsgálja, a pénz térbeli megjelenési formáival, áramlásával, a tőke intézményi és szabályozási hátterével és a pénzmozgások társadalmi és kulturális hatásaival foglalkozik. E viszonylag rövid múltra visszatekintő tudomány választ keres arra, hogy a pénzügyi folyamatok milyen kapcsolatban vannak a regionális fejlödés egyenlőtlenségeivel, különös tekintettel a centrum és a perifériák közötti pénzáramlásokra, a pénzügyi központok kialakulásának térbeli tényezőire, a pénzügyi kapcsolatok és a városhierarchia összefüggéseire (központi áramlások elmélete) és a városokon belüli pénzügyi tér struktúrájára.

A könyv a nemzetközi pénzügyi rendszerek globalizációs folyamatának történeti szempontú bemutatása során kitér arra a sokak által aggodalommal figyelt jelenségre is, hogy a pénzügyi szféra elhatalmasodott a reálszféra felett. „A pénzügyi luftballon óriásira duzzadt", tehát a pénz és az érték szétvált egymástól, mert ma már a spekulatív befektetések hozadéka magasabb, mint a termelö befektetéseké, és az ilyen típusú tőkeforgalom sokszorosan meghaladja a reálszféra tényleges szükségletét. Ez azt is jelenti, hogy a pénznek ez az új funkciója kezdi elhomályosítani a hagyományos közvetítő, olajozó funkcióit, és a nemzetközi jövedelemáramlások nagy része reáltevékenységek nélkül jön létre. Mindez a hagyományos érték- és pénzelméletek zavarait okozza, ebből fakad a „valós” és a ,fiktív” pénz elkülönítésének hipotézise, így a 20. század pénzügytanának számos tétele (pl. a háztartások megtakarítási, befektetési szokásai) is revízióra szorul.

A monográfiában lefedett témák gazdagságát bizonyítja, hogy a Szerző kitér olyan témákra is, mint a pénzügyek szociológiája, ezen belül például a pénzügyi kirekesztésre, ami azt jelenti, hogy a pénzügyi szolgáltatások egyes hátrányos helyzetủ vidékeken vagy hátrányos helyzetủ társadalmi rétegek számára csak korlátozottan érhetők el. A pénzügyi szolgáltatók kivonulnak a kockázatosabb, ugyanakkor 
kevés nyereséget kínáló területekről, és ezt a folyamatot sokszor az állami intervenció sem tudja megakadályozni vagy visszafordítani.

Gál Zoltán sokoldalú érvelésével rámutat arra, hogy a pénzügyi globalizáció térbeli folyamatai számos területen megkérdőjelezik a korábbi jóslatokat, várakozásokat. Egyrészt a nemzetközi piacok integrálódása ellenére továbbra is fennáll a hazai piacok dominanciája, a befektetők előnyben részesítik a földrajzilag közelebb elhelyezkedő befektetési lehetőségeket. Másrészt a piacok földrajzi koncentrációja nem erősödik minden határon túl, a globális pénzügyi központok között a pénzügyi eszközök eloszlásának az arányai nem tolódnak el visszavonhatatlanul. Harmadrészt a technológiai fejlődés és a globalizáció nem enyhítette a távoli földrajzi helyek között meglévő információs aszimmetriát, és nem növelte a nemzetközi pénzügyi rendszerek átláthatóságát sem. Negyedszer, a nemzetközi pénzügyi áramlások iránya nem biztosítja a tőkék volumenének nemzetközi kiegyenlítődését, hanem pontosan az ellenkező irányba hat: a tőke a fejlődő régiókból a fejlett régiókba, illetve legújabban a fejlődő régiók között áramlik - ellent mondva minden eddigi tankönyvi logikának.

Ma már a pénzügyi áramlások jelentős része számítógépes rendszereken keresztül - egy virtuális térben - történik, sok helyen például a portfóliók globális diverzifikációjának lehetőségéröl beszélnek, és azt gondolhatnánk, hogy ezzel szinte megszünik a távolság, a „földrajz végéhez” érkeztünk el. Éppen ellenkezőleg. A modern portfólió- és pénzügyi globalizációs elméletek által sugallt megállapítással szemben - amely a portfóliók földrajzilag is széles körü, azaz globális szintű diverzifikálásának lehetőségeit hangsúlyozza - az empirikus vizsgálatok azt bizonyítják, hogy például az amerikai befektetők részvényportfólióinak $85 \%$-a továbbra is hazai papírokból áll. Sőt, a térbeli távolság az országon belüli befektetések esetében is számít, amennyiben ugyanezek az amerikai befektetők részvényportfólióik harmadát olyan vállalati papírokban tartják, amelyek székhelye a befektetők 250 km-es körzetében található. Egy 2005-ös vizsgálatból az is kitünt, hogy az amerikai háztartásoknak a hazai vállalatokba történő befektetései 3,2\%-kal magasabb hozamot eredményeztek, mint a külföldiek. A hazai piacok iránti részlehajlást (home-bias), ami részben a pénzügyi globalizáció (térbeli) korlátját is jelenti, számos tényező indokolja, amelyeket a szerző a 3.4.1., illetve a 6.3. fejezetekben fejt ki részletesen.

A pénzügyi piacok térbeliségének a fontossága növekszik, és ezt a szakma és az elmélet is igyekszik követni. E jelenség mögött számos gyakorlati vagy technikai ok is meghúzódhat. A Szerző felhívja például arra a figyelmet, hogy milyen fontos szerepe van az időzónáknak a pénzügyi piacokon zajló kereskedés folyamataiban, de továbbra is akadályozzák az ,egyetlen globális pénzügyi központban” való integrációt olyan tényezők, mint a szabályozási és adózási környezet, az adminisztrációs terhek, a vállalati kultúra különbségei, a már említett információs aszimmetria és a jelentős tranzakciós költségek. Összességében a Szerző cáfolja azt a véleményt, mely szerint a fejlődés során a tér leértékelődik, és elveszíti szerepét a távolság és a térbeli differenciák léte, sőt bizonyítja, hogy nemcsak az egyes pénzügyi termékek információs tartalmában, a termékek földrajzi koncentráltsági fokában, de a külön- 
böző pénzügyi piaci szegmensek esetében a földrajzi távolság/közelség jelentőségében is komoly eltérések mutatkoznak.

A globális pénzügyi központok koncentrációja is bizonyítja a térbeliség szerepét, hiszen a helyhez kötött, személyes kapcsolatokon alapuló minőségi információk csak ezekben szerezhetők meg. Sőt, miközben a gazdasági tevékenységek globalizálódnak, a tartós versenyelőny forrásai továbbra is adott földrajzi helyekhez, mint helyi bázisokhoz kötődnek - így összefonódik a globális és a lokális szerveződés (Gál 2000a). A pénzügyi piacok térbeli elhelyezkedését, a nemzetközi pénzügyi központokat, a részpiacok koncentrációját, a tőkeáramlások irányváltozásait, valamint a súlypontok Kína és India felé történő lassú eltolódását a könyv II. része mutatja be. Ugyanakkor nemcsak az eurózóna piaci és monetáris integrálódásának korlátaira hívja fel a Szerző a figyelmet, de arra is, hogy a kínai piacokon továbbra is fennálló, az intézményrendszer alulfejlettségéből, a szabályozás, illetve az információs pool hiányosságaiból (kötöttségeiből) fakadó korlátok a közeljövőben nem teszik Kínát alkalmassá arra - a megtermelt tőke mennyisége ellenére sem -, hogy a jelenlegi globális központokhoz hasonló fejlettségủ pénzügyi központtá váljon. A könyvben külön fejezet foglalkozik a tőzsdék térgazdasági folyamataival, valamint a nemzetközi pénzügyi központok fejlődésével, hálózati kapcsolataival, telepítő és központképző tényezöivel és az offshore központok szerepével.

A pénzügyi tevékenységek nagyfokú diverzifikációja következtében a bankok klasszikus funkciója, a betétgyüjtő-hitelező közvetítés háttérbe szorult, mellyel párhuzamosan hatalmasra nőtt a nem banki pénzügyi rendszer, ugyanakkor a pénzintézetek is részt vesznek a tőkepiaci közvetítésben. A III. rész ezeket a folyamatokat, tehát a dezintermediációt és a pénzügyi szolgáltatók univerzalizálódását járja körül térbeli szempontok alapján. Alfejezeteiben kimerítően foglalkozik az intézményi befektetők szerepével és a transznacionális bankok fejlődésével, azaz a globális bankpiacok kialakulásával és földrajzi jellemzőivel, de a globális integráció korlátaival is.

Ma már nem szemlélhetjük a pénzügyi piacokat úgy, hogy ne vetülne rá a 2007 és 2009 között az egész világon végigsöprő pénzügyi válság árnyéka, mely likviditásibizalmi válságból egy mély gazdasági krízisbe torkollott. Ennek hosszú távú hatásai meghatározóak lesznek a pénzügyi globalizáció jövője szempontjából, és jelentősen átrendezhetik a világ geopolitikai térképét is. Így a könyv $I V$. része a globális pénzügyi válsággal és annak következményeivel foglalkozik, különös tekintettel a térbeli szempontokra. Megismerhetjük a válság kiváltó okait, az időbeli, az ágazatok közötti és a térbeli terjedését, valamint a hosszú távú hatásait. Ellentétben számos korábbi válsággal, a jelenlegi a világ legfejlettebb gazdaságából indult, és onnan terjedt át a feltörekvő országok piacaira. A pénzügyi piacok magas fokú integrációja miatt a válság kezelése és a fertőzés lokalizációja nehézségekbe ütközik, és mivel a fertőzés a globális pénzügyi központokból indult ki, a tőke „menekülési útvonalai” is bezárultak. A fejezet a válság utáni „új korszak” várható változási irányainak felvázolásával zárul.

A könyv a pénzügyi földrajz alapművének számít, melyet kézikönyvként forgathatnak a szakértők és az érdeklődők. Minden egyes oldala azt üzeni, hogy a térbeliség a globalizált pénzvilágnak egy mellőzhetetlen tényezője. Befejezésképp hadd 
idézzük a Szerző szavait: „A könyv mindazoknak íródott, akik kíváncsiak a pénzügyi piacok szereplőinek térbeli elhelyezkedésére, a szereplők illetve a sokféle piaci szegmens között kialakuló kölcsönös függésekre, a pénzügyi információk és a tőke áramlásának sajátosságaira, illetve azokra a térgazdaságtani módszerekre, amelyek a pénzügyi piacok és intézményeik térbeli eloszlását, áramlásait, koncentrációit és szóródását bemutatják."

\section{Irodalom}

Gál Z. (2000a) A regionalizmus kihívásai: a magyarországi bankrendszer fejlődése és területi struktúrája. - Horváth Gy.-Rechnitzer J. (szerk.) Magyarország területi szerkezete és folyamatai az ezredfordulón. MTA RKK, Pécs. 374-396. o.

Gál Z. (2000b) A regionális tudomány új irányzata: a pénzügyi földrajz. - Tér és Társadalom. 2-3. 9-21. o.

Gál, Z. (2009) Banking network. - Kocsis, K.-Schweitzer, F. (eds.) Hungary in Maps. Geographical Research Institute Hungarian Academy of Sciences, Budapest. 178-181. o. 


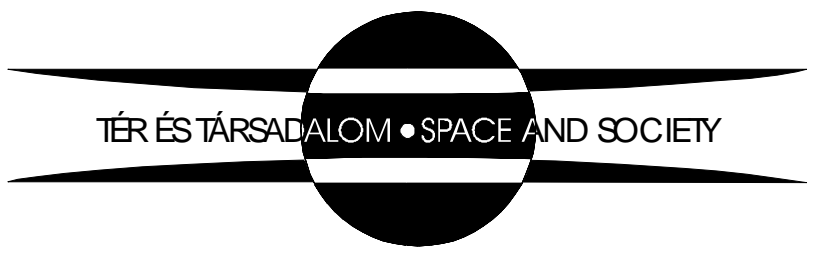

